\title{
Patterns of urinary oestrogen excretion in female golden lion tamarins (Leontopithecus rosalia)
}

\author{
J. A. French and J. A. Stribley \\ Departments of Psychology and Biology, University of Nebraska at Omaha, Omaha, NE 68182, U.S.A.
}

\begin{abstract}
Summary. Daily urine samples were collected from 5 female golden lion tamarins (Leontopithecus rosalia) over a period of 3 or more months, and urinary oestrogen concentrations were determined by radioimmunoassay. Four females exhibited regular patterns of oestrogen excretion, with a peak-to-peak periodicity of $19 \cdot 6 \pm 1.4$ days. Levels of oestrogen excretion tended to vary between, but not within, individual females. Post-partum oestrogen patterns included periods of clear oestrogen cyclicity before conception, with dramatic elevations in oestrogen excretion following conception. Oestrone was the predominant urinary oestrogen excreted by female lion tamarins. Enzyme hydrolysis with Helix pomatia $\beta$-glucuronidase/sulphatase was an efficient method of liberating conjugated oestrogens in tamarin urine. Urinary oestrogen determinations can provide useful information about reproductive status in female lion tamarins.
\end{abstract}

\section{Introduction}

Our understanding of reproductive endocrinology in the marmosets and tamarins (Primates: Family Callitrichidae) has increased tremendously in recent years. One of the methodological advances that has led to such enhanced knowledge is the growing application of radioimmunoassays to the measurement of urinary steroid and peptide hormones. The reproductive cycle in females of several species has been characterized by using these methods (see Brand, 1981; Hodges, Gulick, Czekala \& Lasley, 1981; French, Abbott, Scheffler, Robinson \& Goy, 1983; Epple \& Katz, 1984).

The golden lion tamarin (Leontopithecus rosalia) and related species ( $L$. chrysomelas and $L$. chrysopygus; Rosenberger \& Coimbra-Filho, 1984) are among the world's most endangered primate species (Mittermeier, Coimbra-Filho, Constable, Rylands \& Valle, 1982). In spite of its critical conservation status, virtually nothing is known about the endocrinology of the lion tamarin. In the only published report on endocrine states in golden lion tamarins, Kleiman, Gracey \& Hodgen (1978) measured urinary chorionic gonadotrophin excretion in pregnant females and found detectable levels from 16 to 9 weeks pre partum. Although a reproductive cycle has been identified on the basis of behavioural criteria (Kleiman, 1978), no previous research has addressed the endocrine basis of this cycle. Here we report on patterns of urinary oestrogen excretion in non-pregnant, cyclic female golden lion tamarins.

\section{Materials and Methods}

The 5 golden lion tamarins (Leontopithecus rosalia) were born in captivity. All females were adult and paired with an unrelated adult male. One female had been paired with her mate for about 7 years, and the 4 remaining females were paired with an unrelated male at the onset of the sampling period reported here. Table 1 lists the colony members, ages, and dates of pairing. 
Table 1. Breeding pairs of golden lion tamarins at the University of Nebraska at Omaha

\begin{tabular}{|c|c|c|c|c|c|}
\hline \multicolumn{2}{|c|}{ Animal identification } & \multicolumn{2}{|c|}{$\begin{array}{l}\text { Age at onset } \\
\text { of study } \\
\text { (years) }\end{array}$} & \multirow[b]{2}{*}{ Pairing date } & \multirow[b]{2}{*}{ Housing condition } \\
\hline $\begin{array}{l}\text { Female } \\
\text { ISIS Code* }\end{array}$ & $\begin{array}{c}\text { Male } \\
\text { ISIS Code }\end{array}$ & Female & Male & & \\
\hline $101187(\mathrm{Al})$ & $100068(\mathrm{Be})$ & 8 & 13 & Arrived as pair (1977) & Family Group \\
\hline $104187(\mathrm{Ch})$ & $104753(\mathrm{Sa})$ & 2 & 2 & 14 August 1983 & Pair \\
\hline $104659(\mathrm{Em})$ & $105594(\mathrm{Ru})$ & 1.5 & 2 & 9 January 1984 & Pair \\
\hline $102801(\mathrm{Ro})$ & $101666(\mathrm{Le})$ & 4 & 8 & 8 September 1983 & Pair \\
\hline $100997(\mathrm{Lu})$ & $105610(\mathrm{Po})$ & 9 & 5 & 24 August 1983 & Pair \\
\hline
\end{tabular}

* International Species Inventory System.

The animals were housed in large wood and wire mesh home cages which ranged in size from $1 \times 2 \times 2 \cdot 1 \mathrm{~m}$ to $2 \times 2 \times 2 \cdot 1 \mathrm{~m}$. The animals were provided with food (commercial marmoset diet, fresh fruit and vegetables, eggs, dairy products, and a vitamin supplement) and fresh bottles of water once each day. Natural sunlight was supplemented with overhead fluorescent lighting from 07:00 to 19:00 $\mathrm{h}$. The cages were maintained in a large colony room in which acoustic and olfactory contact, but not visual contact, among animals housed in different cages was possible.

The golden lion tamarin is listed by the U.S. Fish and Wildlife Service and in the IUCN Red Data Book as an endangered species. The University of Nebraska at Omaha is a signatory member of the Cooperative Management Agreement for the golden lion tamarin.

Sample collection. Urine samples from each female were collected daily (7 days per week) for at least 3 months for each female. Sample collection typically occurred in the early or mid-morning (07:00 to 11:00 h). A collection procedure that eliminated capture and restraint was adopted. Large aluminium pans were placed on the floor of the cage. Females were watched until they urinated on the pans. When there was contamination by urine from other animals, the sample was discarded and an additional uncontaminated sample was collected. After a female urinated (usually $0.5-3.0 \mathrm{ml}$ ), the sample was pipetted into a vial, centrifuged briefly to remove detritus, and frozen at $-40^{\circ} \mathrm{C}$ until assayed. All of the pans were washed after use with a mild detergent, rinsed with hot water, and allowed to air dry before use again the next day. In addition to minimizing individual stress, this method of urine collection had the advantage of minimizing the colony disruption associated with capture and restraint.

Oestrogen assay. Samples were thawed and $5 \mu \mathrm{l}$ of each urine sample were diluted to $5.0 \mathrm{ml}$ in phosphate-buffered saline (PBS, pH 7.0). Samples were hydrolysed by the addition of $25 \mu \mathrm{l}$ $\beta$-glucuronidase/sulphatase (2500 Fishman Units; Type H-2, Sigma Chemical Co., St Louis, MO). This mixture was incubated overnight at $37^{\circ} \mathrm{C}$. The efficiency of this hydrolysis procedure in cleaving glucuronide and sulphate conjugates from oestrogens was monitored in two ways (see 'Assay validation' below).

Duplicate aliquants of each hydrolysed sample (5-200 $\mu$ l diluent, $0.005-0.200 \mu$ l actual urine volume) were further diluted to $1.0 \mathrm{ml}$ in PBS. The volume of urine assayed depended in part on the creatinine content of the sample. Oestrogens were extracted with $5.0 \mathrm{ml}$ freshly opened diethyl ether (AR). The samples were shaken for $10 \mathrm{~min}$, the supernatant was decanted into assay tubes, and evaporated under a stream of nitrogen. Procedural losses during extraction were monitored by the recovery of small amounts (1000 c.p.m.) of $\left[2,4,6,7(\mathrm{~N})-{ }^{3} \mathrm{H}\right]$ oestrone added to PBS and extracted with ether. Recovery of labelled oestrone was $91.9 \pm 2.8 \%(n=9$; mean \pm s.d. throughout, except where noted). Unknown values were corrected for procedural losses by the recovery estimates.

Assay tubes contained the sample, $0.1 \mathrm{ml}\left[{ }^{3} \mathrm{H}\right]$ oestrone trace $(1.04 \mathrm{pg}$; sp. act. $86.6 \mathrm{Ci} / \mathrm{mmol}$ : New England Nuclear, Boston, MA) and $0.1 \mathrm{ml}$ oestrone antiserum (rabbit anti-oestrone6-thyroglobulin: Miles Laboratories, Elkhart, IN). The oestrone antiserum was diluted so that 
about $50 \%$ of the tritiated oestrone was bound in the absence of unlabelled steroid. The crossreactivity values for the oestrone antiserum provided by the supplier were $0 \cdot 1 \%$ for oestradiol- $17 \beta$, and $<0.01 \%$ for oestriol, progesterone, testosterone, dihydrotestosterone, androstenedione, and 17-hydroxyprogesterone. A triplicate oestrone standard curve (dose range 5-300 pg) was included for each sample set (30-35 samples in duplicate). After incubation at $4^{\circ} \mathrm{C}$ for $15-18 \mathrm{~h}$, separation of free from bound steroid was accomplished by the addition of $1.0 \mathrm{ml}$ dextran-coated charcoal in PBS. After centrifugation, the supernatant containing the bound steroid was poured into vials and $10 \mathrm{ml}$ scintillation cocktail was added. Each vial was counted for $10 \mathrm{~min}$ or 10000 counts.

Buffer blanks were $1.46 \pm 1.13 \mathrm{pg} /$ tube $(n=8)$. Assay sensitivity was thus set at $3.72 \mathrm{pg} /$ tube $($ mean +2 s.d.). A urine pool from adult females was assayed in triplicate with each set of samples. Intra-assay variation, calculated as the mean coefficient of variation for the 3 samples in each assay, was $9 \cdot 4 \%$. Inter-assay variability was $13 \cdot 0 \%(n=8)$.

Creatinine assay. The oestrogen concentration of urine samples was divided by the creatinine concentration of the sample to control for variable fluid intake and output (Klopper, 1976; Hodges et al., 1981). Creatinine was assayed by a modified Jaffé reaction end-point assay (Tietz, 1976). Urine was combined with picric acid, $\mathrm{NaOH}$, and glass-distilled water in optical cuvettes, and absorbance at $500 \mathrm{~nm}$ was read on a spectrophotometer. Intra-assay variability was $1.9 \%(n=11)$ for a dilute urine pool and $0.4 \%(n=9)$ for a concentrated urine pool. Inter-assay variability was $7 \cdot 1 \%(n=23)$ for the dilute urine pool and $1 \cdot 1 \%(n=28)$ for the concentrated urine pool.

Assay validation and hydrolysis efficiency. The biological validation of the oestrogen assay was accomplished by assaying in triplicate serial dilutions of an adult female urine pool. In the serial dilution assays, volumes of urine assayed varied over 2 orders of magnitude $(0.005$ to $0.5 \mu \mathrm{l})$. There was a positive correlation between the volume of urine assayed and estimated oestrogen concentrations (pg/tube; Pearson product moment correlation; $r_{\mathbf{P}}=0.999$ ), indicating that the volume of urine assayed did not influence the estimation of oestrogen concentrations.

Several assays were performed to determine the relative contributions of oestrone and oestradiol to the values obtained with unchromatographed urine samples and the oestrone antiserum (hereafter referred to as 'oestrogen'). Samples from an adult female urine pool were subjected to chromatographic separation of oestrone and oestradiol. Sephadex LH-20 (Pharmacia Fine Chemicals, Piscataway, NJ) was used as the solid phase and dichloromethane:methanol (98:2, $\mathrm{v} / \mathrm{v}$ ) was used as the liquid phase. An oestradiol antiserum (rabbit anti-17 $\beta$-oestradiol-6-BSA: Miles Laboratories) was used to assay oestradiol. The cross-reactivity values for the antiserum provided by the supplier were $1.6 \%$ for $17 \alpha$-oestradiol, $1.4 \%$ for oestrone, and $<0.01 \%$ for progesterone and testosterone. Recovery of ${ }^{3} \mathrm{H}$-labelled oestradiol was $69 \cdot 4 \pm 3.3 \%(n=2)$ and the values of unknown samples were corrected for procedural losses. Assay sensitivity was $2 \cdot 2 \mathrm{pg} /$ tube. Assay variation values have been previously determined for this assay system (French et al., 1983). Intra-assay variation was $6.7 \%$ and inter-assay variation was $14 \cdot 7 \%(n=8)$.

To monitor the possibility that the relative values of oestrone and oestradiol excretion varied during the reproductive cycle, samples from peak and nadir phases of a urinary oestrogen cycle from a single female were assayed for oestrone and oestradiol. These values were also compared with the values obtained for the unchromatographed oestrogen.

The efficiency of the $\beta$-glucuronidase/sulphatase preparation in hydrolysing conjugated oestrogens was tested in two ways. First, tubes with $45 \mathrm{pg}\left[6,7-{ }^{3} \mathrm{H}(\mathrm{N})\right]$ oestrone sulphate (New England Nuclear) or $34.5 \mathrm{pg}\left[6,7-{ }^{3} \mathrm{H}(\mathrm{N})\right]$ oestradiol-17ß-D-glucuronide (New England Nuclear) were extracted with $5 \mathrm{ml}$ diethyl ether: (i) after incubation with the enzyme preparation or (ii) after incubation in the absence of the enzyme. The ether extracts were evaporated, reconstituted in scintillation cocktail, counted for $10 \mathrm{~min}$, and recovery of labelled steroids was determined. Second, a dose-response curve was determined for the enzyme. Triplicate aliquants of urine from a cyclic adult female were incubated with $20,10,5$ or $0 \mu$ l of enzyme $(2000,1000,500$, and 0 Fishman units, 


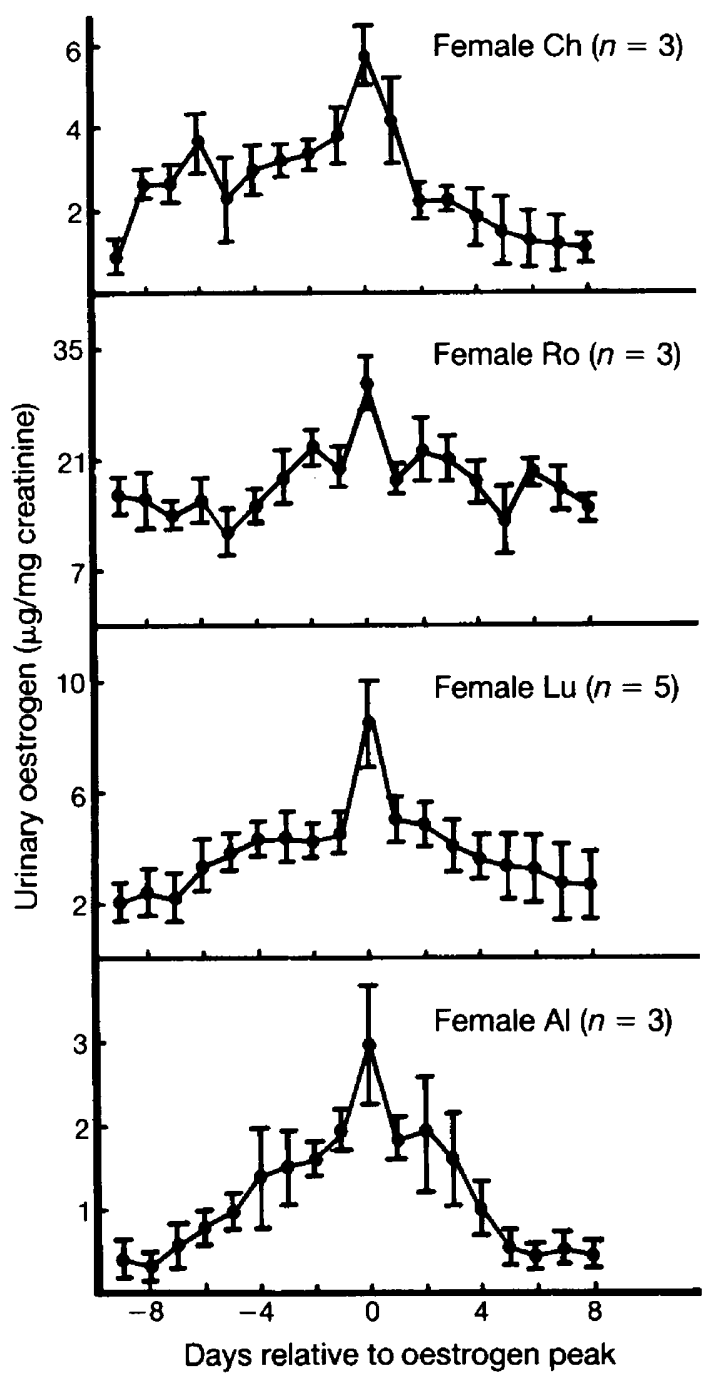

Text-fig. 1. Urinary oestrogen cycles for 4 female golden lion tamarins. Cycles are normalized to the day of peak oestrogen excretion ( = Day 0 ). Vertical lines represent \pm 1 s.e.m.

respectively). After incubation, the samples were chromatographed as described by French et al. (1983) and assayed for oestrone and oestradiol.

\section{Results}

Over 400 samples were assayed for oestrogen. Urinary oestrogen concentrations ranged from 0.064 to $48.05 \mu \mathrm{g} / \mathrm{ml}$. Urinary creatinine concentrations ranged from 0.057 to $2.630 \mathrm{mg} / \mathrm{ml}$. Creatinine-corrected oestrogen concentrations ranged from 0.070 to $35.939 \mu \mathrm{g} / \mathrm{mg}$ creatinine.

Oestrogen cycles

Four of the 5 females exhibited regular cycles in oestrogen excretion. Composite cycles are shown in Text-fig. 1. Successive cycles were aligned with respect to the day of peak oestrogen 
Table 2. Urinary oestrogen cycle details for female golden lion tamarins

\begin{tabular}{|c|c|c|c|c|c|}
\hline Female & $\begin{array}{l}\text { No. of } \\
\text { cycles }\end{array}$ & $\begin{array}{l}\text { Peak-to-peak } \\
\text { interval } \\
\text { (days) }\end{array}$ & Range & $\begin{array}{c}\text { Peak } \\
\text { oestrogen } \\
(\mu \mathrm{g} / \mathrm{mg} \mathrm{Cr})\end{array}$ & $\begin{array}{c}\text { Nadir } \\
\text { oestrogen } \\
(\mu \mathrm{g} / \mathrm{mg} \mathrm{Cr})\end{array}$ \\
\hline $\mathrm{Ch}$ & 3 & $16 \cdot 0 \pm 1 \cdot 15$ & $14-18$ & $5.70 \pm 0.79$ & $0.77 \pm 0.35$ \\
\hline Ro & 3 & $21 \cdot 0 \pm 4 \cdot 16$ & $15-29$ & $30.63 \pm 2.95$ & $15 \cdot 43 \pm 0.22$ \\
\hline $\mathrm{Lu}$ & 5 & $23 \cdot 4 \pm 3 \cdot 11$ & $19-31$ & $8 \cdot 48 \pm 2 \cdot 17$ & $2 \cdot 10 \pm 0 \cdot 61$ \\
\hline $\mathrm{Al}$ & 3 & $17.25 \pm 0.85$ & $15-19$ & $2.93 \pm 0.67$ & $0.33 \pm 0.13$ \\
\hline Mean & 14 & $19.56 \pm 1 \cdot 41$ & $14-31$ & $11.93 \pm 6.33$ & $4 \cdot 66 \pm 3 \cdot 61$ \\
\hline
\end{tabular}

All values indicate mean \pm s.e.m.

Table 3. Oestrogen concentrations in two urine pools with and without chromatographic separation of oestradiol and oestrone

\begin{tabular}{lccccc}
\hline & \multicolumn{2}{c}{ Oestrone } & & \multicolumn{2}{c}{ Oestradiol } \\
\cline { 2 - 3 } \cline { 5 - 6 } \multicolumn{1}{c}{ Urine pool } & \multicolumn{1}{c}{ With } & Without & & With & Without \\
\hline Adult female & $14.03 \pm 1 \cdot 08^{*}$ & $16.32 \pm 1 \cdot 12$ & & $0 \cdot 083 \pm 0.005$ & $0 \cdot 710 \pm 0 \cdot 164$ \\
Young adult female & $3.83 \pm 0 \cdot 19$ & $4.58 \pm 0.28$ & & $0 \cdot 168 \pm 0.008$ & $0 \cdot 329 \pm 0.035$ \\
\hline
\end{tabular}

*Values represent $\mu \mathrm{g} / \mathrm{ml}$ (mean \pm s.e.m.). All pools assayed in quadruplicate.

excretion (= Day 0$)$. In all females the cycles were characterized by a gradual rise in oestrogen excretion until the peak, then a rapid decrease in excretion until a return to base levels of excretion by Day +5 .

The average peak-to-peak duration for 14 cycles from 4 females (3-5 cycles per female) was $19.6 \pm 1.4$ days (mean \pm s.e.m.). The median cycle length was 19 days. Cycle length ranged from 14 to 31 days. Table 2 displays individual cycle characteristics for each female. Concentrations of oestrogen excretion were variable amongst females, with individual peak values ranging from 2.93 to $30.63 \mu \mathrm{g} / \mathrm{mg}$ creatinine and mean nadir values ranging from 0.33 to $15.43 \mu \mathrm{g} / \mathrm{mg}$ creatinine. There was, however, a consistent relationship between peak and nadir oestrogen levels within a single female. Females with higher peak oestrogen levels also tended to have higher nadir levels $\left(r_{\mathrm{P}}=0.93 ; P<0.001\right)$.

The fifth female in the study, Female Em, showed no evidence of ovarian cyclicity. For the duration of the sampling period, she exhibited low and acyclic patterns of oestrogen excretion. Spikes in oestrogen excretion were rare and were at concentrations far below the peak values for cyclic females. Of 43 samples, only 5 had oestrogen concentrations exceeding $1.0 \mu \mathrm{g} / \mathrm{mg}$ creatinine, and no samples exceeded $1.5 \mu \mathrm{g} / \mathrm{mg}$ creatinine. Female Em was the youngest female in the study ( 1.5 years) and was housed in her family group immediately before the beginning of urine sampling.

The chromatographic separation of oestrone and oestradiol revealed that oestrone was the predominant urinary oestrogen excreted by female golden lion tamarins. Table 3 shows urinary oestrone and oestradiol concentrations in pooled urine from adult females and in urine from a young adult female. In both samples, oestrone was excreted at much higher concentrations than oestradiol. In addition, while urinary oestradiol levels in the urine of the young adult female were twice as high as in the pooled urine of adult females, levels of urinary oestrone were 4 times higher in the adult urine than in that of the young female.

Table 4 presents urinary oestrogen values for urine samples collected during the peak and nadir phases of a reproductive cycle in a single female. During both phases of the cycle, oestrone was excreted in higher concentrations than oestradiol. Peak to nadir ratios were higher for oestrone than for oestradiol, indicating a greater variability in excretion of oestrone throughout the cycle. 
Table 4. Urinary oestrone, oestradiol, and 'oestrogen' concentrations in urine samples from different phases of the oestrogen cycle

\begin{tabular}{lccccc}
\hline \multicolumn{1}{c}{ Sample } & $\begin{array}{c}\text { Oestrone } \\
(\mu \mathrm{g} / \mathrm{mg} \mathrm{Cr})\end{array}$ & $\begin{array}{c}\text { Oestradiol } \\
(\mu \mathrm{g} / \mathrm{mg} \mathrm{Cr})\end{array}$ & $\begin{array}{c}\text { Oestrone: } \\
\text { oestradiol } \\
\text { ratio }\end{array}$ & $\begin{array}{c}\text { Oestrogen } \\
(\mu \mathrm{g} / \mathrm{mg} \mathrm{Cr})\end{array}$ & $\begin{array}{c}\text { Creatinine } \\
(\mathrm{mg} / \mathrm{ml})\end{array}$ \\
\hline Peak $(n=3)$ & $2 \cdot 37 \pm 1.00$ & $0.089 \pm 0.028$ & 26.62 & $3.38 \pm 1.47$ & $0.87 \pm 0.21$ \\
Nadir $(n=3)$ & $0.55 \pm 0 \cdot 21$ & $0.039 \pm 0.009$ & $14 \cdot 12$ & $0.94 \pm 0.29$ & $0.82 \pm 0.21$ \\
Overall $(n=6)$ & $1.46 \pm 0.62$ & $0.064 \pm 0.018$ & 22.81 & $2 \cdot 16 \pm 0.88$ & $0.84 \pm 0.13$ \\
\hline
\end{tabular}

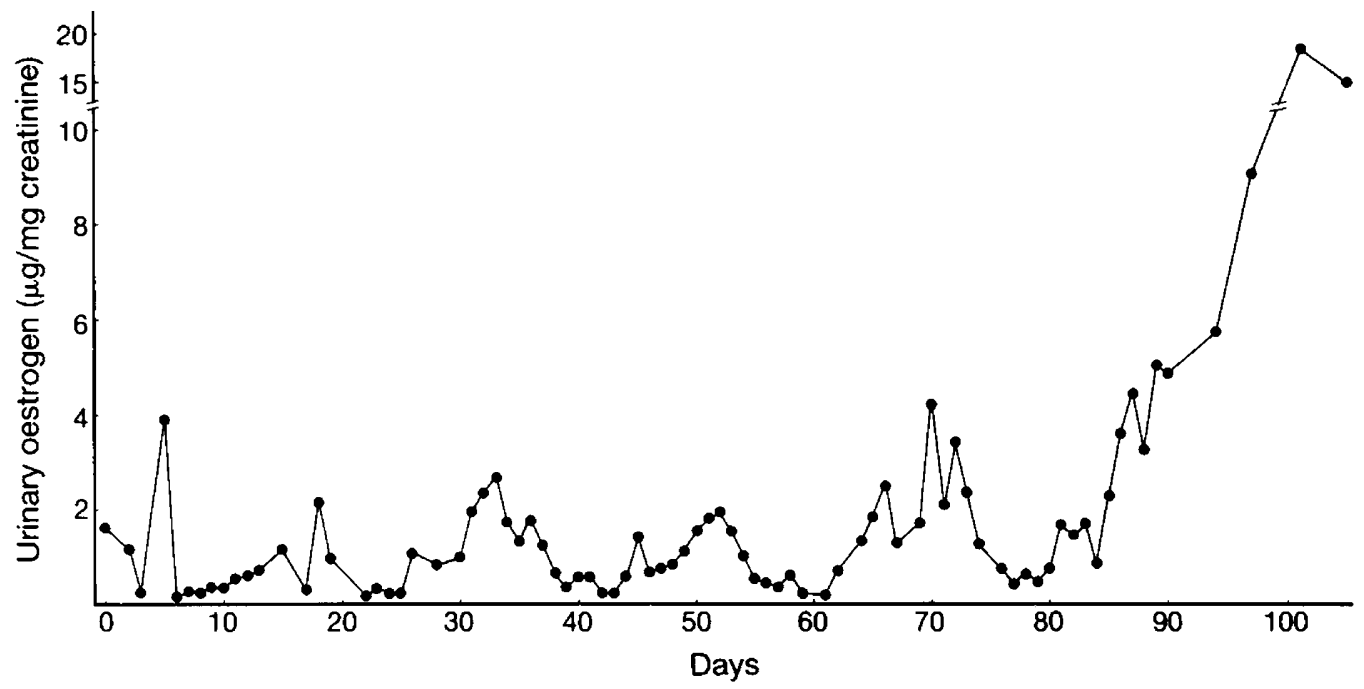

Text-fig. 2. Patterns of post-partum oestrogen excretion in Female A1. Parturition occurred on Day 0 of sampling schedule. Estimated week of conception is Days 70-77 (see text).

The peak to nadir ratio for oestrogen resembled that for oestrone. Creatinine excretion did not differ across phases of the reproductive cycle.

Pearson product moment correlations were calculated among oestrone, oestradiol, 'oestrogen', and creatinine values for 6 samples. There were highly significant positive correlations between all oestrogen measures (oestrone-oestradiol, $r_{\mathrm{p}}=0.989$; oestrone-oestrogen, $r_{\mathrm{P}}=0.998$; oestradioloestrogen, $r_{\mathrm{P}}=0.987 ; P<0.001$ ). Correlations between creatinine content of the urine sample and oestrone, oestradiol, and oestrogen were not significant (all $r_{\mathrm{P}}<0.647$ ).

\section{Post-parturient oestrogen excretion}

Samples were collected from one female (A1) for 3 months from the day of parturition. Oestrogen excretion profiles for this female are shown in Text-fig. 2. After a sharp spike in oestrogen excretion 5 days post partum, the first regular cycle began 25 days post partum. Three clear cycles occurred with peaks on Days 33, 52, and 70. Oestrogen excretion rose 7- to 10-fold on Days 90 and beyond. This female gave birth to triplets 199 days post partum.

\section{Enzyme hydrolysis}

Table 5 shows the recovery estimation of ${ }^{3} \mathrm{H}$-labelled conjugated oestrogens with and without enzyme hydrolysis. Hydrolysis of glucuronide- and sulphate-conjugated steroid was virtually 
Table 5. Efficiency of $\beta$-glucuronidase/sulphatase enzyme hydrolysis of ${ }^{3} \mathrm{H}$-labelled conjugated oestrogens in tamarin urine*

\begin{tabular}{|c|c|c|c|c|}
\hline \multirow[b]{2}{*}{ Sample treatment } & \multicolumn{2}{|c|}{ Oestrone sulphate } & \multicolumn{2}{|c|}{ Oestradiol-17 $\beta$-D-glucuronide } \\
\hline & d.p.m. $\dagger$ & $\%$ Initial & d.p.m. $\dagger^{\dagger}$ & $\%$ Initial \\
\hline Initial sample & $5757 \cdot 5 \pm 122$ & 100.0 & $10292 \cdot 8 \pm 130$ & $100 \cdot 0$ \\
\hline Enzyme added & $5414.0 \pm 151$ & 94.0 & $10321.5 \pm 118.8$ & $100 \cdot 3$ \\
\hline No enzyme & $186 \cdot 3 \pm 11$ & $3 \cdot 2$ & $4382.8 \pm 172.0$ & $42 \cdot 6$ \\
\hline
\end{tabular}

All samples extracted in quadruplicate, mean \pm s.d.

* Initial mass of oestrone sulphate, $45 \mathrm{pg} /$ tube; initial mass of oestradiol-17ß-D-glucuronide, $34.5 \mathrm{pg} / \mathrm{tube}$.

$\doteqdot$ d.p.m. = decays per minute.

Table 6. Dose-response effectiveness of $\beta$-glucuronidase enzyme hydrolysis on tamarin urine samples

\begin{tabular}{|c|c|c|c|c|c|}
\hline \multirow[b]{2}{*}{ Enzyme $(\mu \mathrm{l})$} & \multirow{2}{*}{$\begin{array}{c}\text { Fishman } \\
\text { Units }\end{array}$} & \multicolumn{2}{|c|}{ Oestrone } & \multicolumn{2}{|c|}{ Oestradiol } \\
\hline & & $\mathrm{ng} / \mathrm{ml}$ & $\%^{*}$ & $\mathrm{ng} / \mathrm{ml}$ & $\% *$ \\
\hline 20 & 2000 & $589 \cdot 14$ & 100.0 & 5.357 & $100 \cdot 0$ \\
\hline 10 & 1000 & $604 \cdot 15$ & 102.5 & 5.496 & $102 \cdot 6$ \\
\hline 5 & 500 & 578.76 & $98 \cdot 2$ & $4 \cdot 188$ & $78 \cdot 2$ \\
\hline 0 & 0 & 13.91 & 2.4 & 0.130 & 2.4 \\
\hline
\end{tabular}

All samples assayed in triplicate, urine from cycling adult female.

* Percentage of sample hydrolysed with $20 \mu \mathrm{l} \beta$-glucuronidase.

complete with $25 \mu \mathrm{l} \beta$-glucuronidase/sulphatase. Extraction without enzyme hydrolysis led to a greatly reduced recovery of labelled oestrogens. Table 6 presents the dose-response function for the $\beta$-glucuronidase/sulphatase preparation in hydrolysing conjugated oestrogens in tamarin urine. Hydrolysis of urine samples with as little as $5 \mu 1$ (500 Fishman Units) of the enzyme was sufficient to hydrolyse a substantial proportion of the conjugated oestrogens in tamarin urine. Urine samples in this study were routinely hydrolysed with $25 \mu$ l of the enzyme preparation.

\section{Discussion}

We have demonstrated that female golden lion tamarins exhibit 19-day cycles in urinary oestrogen excretion. Oestrone was excreted at 14- to 26-fold higher concentrations than oestradiol. All measures of oestrogen excretion, however, including a measure of unchromatographed urine assayed with an oestrone antiserum ('oestrogen') were positively correlated $(P<0.001)$. Levels of oestrogen excretion among females were variable, but were generally consistent within an individual female. Oestrogen excretion after parturition was monitored, and several oestrogen cycles were noted before the onset of a subsequent pregnancy.

The results presented here describe for the first time the endocrine characteristics of the ovarian cycle in female golden lion tamarins. The cycle length (19.6 \pm 1.4 days) is shorter than the ovarian cycle reported for captive-born common marmosets (28-30 days: Harding, Hulme, Lunn, Henderson \& Aitken, 1982; Hearn, 1982), is slightly shorter than that in cotton-top tamarins (23 days: Brand, 1981; French et al., 1983), and is very similar to the cycle length in the saddleback tamarin (18 days: Hodges et al., 1981; Epple \& Katz, 1982). The oestrogen cycle length of the golden lion tamarin compares favourably with the behavioural oestrous cycle length proposed by Kleiman (1978) for this species. She reported that, in certain pairs, peaks in sexual activity were 
observed with a 14- to 21-day periodicity. The shortest oestrogen cycle documented in the present study was 14 days, and the longest was 31 days. It is likely, therefore, that the behavioural oestrous cycles noted by Kleiman (1978) were associated with ovarian cyclicity. However, because not all pairs studied by Kleiman (1978) exhibited a behavioural oestrus, the physiological monitoring of ovarian cycles provides a more reliable method of fertility assessment.

Individual females varied widely in levels of oestrogen excretion, with mean peak values ranging from 30.63 to $2.93 \mu \mathrm{g} / \mathrm{mg}$ creatinine and mean nadir values ranging from 15.43 to $0.33 \mu \mathrm{g} / \mathrm{mg}$ creatinine. However, inspection of Text-fig. 1 reveals that the qualitative pattern of oestrogen excretion across the cycle was similar for all females. These findings suggest that single samples or short sampling periods are not sufficient to provide useful information regarding a female's reproductive status. As in the cotton-top tamarin (French et al., 1983) and saddleback tamarin (Epple \& Katz, 1982), long-term sampling and oestrogen determinations are required to give successful monitoring of reproductive condition in female lion tamarins.

The source of the individual variations in excreted oestrogen levels is not clear. Possibilities include differential water intake and output, differential creatine and creatinine metabolism and excretion (Klopper, 1976), individual differences in hepatic or renal metabolism and clearance of steroids (Diczfalusy \& Levitz, 1970), or, possibly, individual differences in plasma concentrations. The high levels of oestrogen excreted in the urine of golden lion tamarin females $(\mu \mathrm{g} / \mathrm{mg}$ creatinine) are similar in magnitude to levels observed in other tamarins and marmosets (Lunn, 1978; Brand, 1981; Epple \& Katz, 1982), and are characteristically higher than levels of urinary oestrogens in prosimians, Old World monkeys, and apes (Czekala, Hodges \& Lasley, 1981; Lippold, 1981; Shideler, Czekala, Benirschke \& Lasley, 1983a; Shideler, Czekala, Kasman, Lindburg \& Lasley, 1983b). High levels of excreted oestrogens may be related to the extremely high levels of circulating steroids as reported for marmosets and tamarins (Chambers \& Hearn, 1979; Torii, Utsu \& Tanioka, 1981).

Analysis of urine samples from the post-partum period indicated that ovarian cyclicity began about 20 days after parturition (Text-fig. 2). At least 3 cycles were observed before conception and subsequent pregnancy. In the absence of confirming LH or progesterone metabolite assays, however, it cannot be determined whether the cycles represent ovulatory or anovulatory cycles. The dramatic rise in levels of excreted oestrogens noted around the time of pregnancy initiation in the lion tamarin has also been documented in the common marmoset. In this species, concentrations of urinary oestrone-3-sulphate rose and remained elevated beginning about 10 days after ovulation in the conception cycle (Eastman, Makawiti, Collins \& Hodges, 1984). If the same dynamics of early oestrogen excretion hold for golden lion tamarins, this suggests that conception occurred about 70-77 days post partum in Female A1. This estimate of the day of conception yields a gestation period of 122-129 days. This period is substantially shorter than for other callitrichids (140-160 days: Wolfe, Deinhardt, Ogden, Adams \& Fisher, 1975; French, 1983), but is consistent with previous estimates of gestation length for lion tamarins based on behavioural and management criteria (Kleiman, 1978; Wilson, 1978).

The early dramatic rise in oestrogen excretion associated with pregnancy may be a valuable tool from a reproductive management perspective. It potentially represents an endocrine marker of pregnancy within 2 weeks of fertilization, whereas changes in urinary chorionic gonadotrophin associated with pregnancy are not detectable until 1 month or more after fertilization (Kleiman et al., 1978).

The relative proportions of oestrone and oestradiol excreted in the urine of golden lion tamarin females resembled those reported for cotton-top tamarins (Saguinus o. oedipus: French et al., 1983; Hodges \& Eastman, 1984) and saddleback tamarins (S. f. fuscicollis: Epple \& Katz, 1982, 1984). In all 3 species, oestrone is the predominant urinary oestrogen. This is in contrast to the common marmoset (Callithrix j. jacchus) in which oestradiol is reported to be the predominant urinary oestrogen in cyclic and pregnant females (Shackleton, 1974, 1975; Heger \& Neubert, 1983; Eastman et al., 1984; Hodges \& Eastman, 1984). Oestrone is the major oestrogen component 
excreted in the urine of a variety of primate forms (e.g. Lemur variegatus: Shideler et al., 1983a; Aotus trivirgatus: Bonney \& Setchell, 1980; Presbytis entellus entellus: Shandilya, Ramaswami \& Shandilya, 1976; Pongo pygmaeus: Collins, Graham \& Preedy, 1975; Pan troglodytes: Graham, Collins, Robinson \& Preedy, 1972).

It has been suggested that the hydrolysis of oestrogen conjugates in tamarin urine with enzyme derived from Helix pomatia may be ineffective or inefficient, especially for oestradiol glucuronide and, therefore, may lead to an underestimation of levels of excreted oestrogens (Eastman et al., 1984; Hodges \& Eastman, 1984). However, the high percentage of recovery of ${ }^{3} \mathrm{H}$-labelled oestrone and oestradiol after ether extraction (Table 5) indicates that the Helix pomatia enzyme preparation used in this and other studies has potent sulphatase and glucuronidase activity. In addition, the dose-response analysis of enzyme hydrolysis (Table 6) revealed that the volume of enzyme used for routinely hydrolysing samples $(25 \mu \mathrm{l})$ was sufficient to yield a maximal cleavage of conjugated oestrone and oestradiol in tamarin urine. Several workers have developed assays to measure conjugated urinary steroids directly with an antiserum specific to the steroid conjugate (Bonney, Dixson \& Fleming, 1979; Shideler et al., 1983b; Eastman et al., 1984). It would be of interest to compare amounts of urinary oestrogen conjugates measured directly with the amounts of hydrolysed oestrogens in female lion tamarin urine.

The findings presented in this paper reaffirm the usefulness of monitoring ovarian cyclicity in nonhuman primates by measuring the excretion of urinary oestrogens by radioimmunoassay. The technique has the added advantage of minimizing stress and disturbance, which is of central importance when dealing with concurrent behavioural observations, working with an endangered species, or both. However, the detailed timing of significant reproductive events, such as ovulation, fertilization, and implantation, and the reflection of these events by the excretion of steroid metabolites in the urine remain to be established.

We thank Lisa Maitland for assistance in urine collections; Steve Barnhart, Jena Janovy, and Lori Umstead for help with colony maintenance; W. deGraw and S. Hendricks for comments on earlier versions of this manuscript; Dr Devra Kleiman and the National Zoological Park for the loan of animals; the Golden Lion Tamarin Management Committee for allowing us to establish a research colony of L. rosalia at the University of Nebraska at Omaha; and Dr Lee Simmons and Dr J. Andrew Teare of the Henry Doorly Zoo, Omaha, Nebraska, for veterinary support for the colony. The work was supported by funds from the University Committee on Research.

\section{References}

Bonney, R.C. \& Setchell, K.D.R. (1980) The excretion of gonadal steroids during the reproductive cycle of the owl monkey (Aotus trivirgatus). J. Steroid Biochem. $12,417-422$.

Bonney, R.C., Dixson, A.F. \& Fleming, D. (1979) Cyclic changes in the circulating and urinary levels of ovarian steroids in the adult female owl monkey (Aotus trivirgatus). J. Reprod. Fert. 56, 271-280.

Brand, H.M. (1981). Urinary oestrogen excretion in the female cotton-topped tamarin (Saguinus oedipus oedipus). J. Reprod. Fert. 62, 467-473.

Chambers, P.L. \& Hearn, J.P. (1979) Peripheral plasma levels of progesterone, oestradiol-17 $\beta$, oestrone, testosterone, androstenedione and chorionic gonadotrophin during pregnancy in the marmoset monkey, Callithrix jacchus. J. Reprod. Fert. 56, 23-32.

Collins, D.C., Graham, C.E. \& Preedy, J.R.K. (1975) Identification and measurement of urinary oestrone, estradiol-17 $\beta$, estriol, and pregnanediol and androsterone during the menstrual cycle of the orangutan. Endocrinology 96, 93-101.

Czekala, N.M., Hodges, J.K. \& Lasley, B.L. (1981) Pregnancy monitoring in diverse primate species by estrogen and bioactive luteinizing hormone determinations in small volumes of urine. J. med. Primatol. $10,1-15$.

Diczfalusy, E. \& Levitz, M. (1970) Formation, metabolism, and transportation of estrogen conjugates. In Chemical and Biological Aspects of Steroid Conjugation, pp. 291-320. Eds S. Bernstein \& S. Solomon. Springer-Verlag, New York.

Eastman, S.-A.K., Makawiti, D.W., Collins, W.P. \& Hodges, J.K. (1984) Pattern of excretion of urinary steroid metabolites during the ovarian cycle and pregnancy in the marmoset monkey. J. Endocr. 102, 19-26. 
Epple, G. \& Katz, Y. (1982) The saddleback tamarin and other tamarins. In Reproduction in New World Primates, pp. 115-148. Ed. J. P. Hearn. MTP Press, Lancaster.

Epple, G. \& Katz, Y. (1984) Social influences on estrogen excretion and ovarian cyclicity in saddle back tamarins (Saguinus fuscicollis). Am. J. Primatol. 6, 215-228.

French, J.A. (1983) Lactation and fertility: an examination of nursing and interbirth intervals in cotton-top tamarins (Saguinus o. oedipus). Folia primatol. 40, 276-282.

French, J.A., Abbott, D.H., Schefiler, G., Robinson, J.A. \& Goy, R.W. (1983) Cyclic excretion of urinary oestrogens in female tamarins (Saguinus oedipus). $J$. Reprod. Fert. 68, 177-184.

Graham, C.E., Collins, D.C., Robinson, H. \& Preedy, J.R.K. (1972) Urinary levels of estrogens and pregnanediol and plasma levels of progesterone during the menstrual cycle of the chimpanzee: relationship to the sexual swelling. Endocrinology 91, 13-24.

Harding, R.D., Hulme, M.J., Lunn, S.F., Henderson, C. \& Aitken, R.J. (1982) Plasma progesterone levels throughout the ovarian cycle of the common marmoset (Callithrix jacchus). J. med. Primatol. 11, 43-51.

Hearn, J.P. (1982) The common marmoset (Callithrix jacchus). In Reproduction in New World Primates, pp. 181-215. Ed. J. P. Hearn. MTP Press, Lancaster.

Heger, H.W. \& Neubert, D. (1983) Timing of ovulation and implantation in the common marmoset, Callithrix jacchus, by monitoring of estrogens and $6 \beta$-hydroxypregnanolone in urine. Arch. Toxicol. 54, 41-52.

Hodges, J.K. \& Eastman, S.-A.K. (1984) Monitoring ovarian function in marmosets and tamarins by the measurement of urinary estrogen metabolites. $A m$. J. Primatol. 6, 187-198.

Hodges, J.K., Gulick, B.A., Czekala, N.M. \& Lasley, B.L. (1981) Comparison of urinary oestrogen excretion in South American primates. J. Reprod. Fert. 61, 83-90.

Kleiman, D.G. (1978) Characteristics of reproductive and sociosexual interactions in pairs of lion tamarins (Leontopithecus rosalia) during the reproductive cycle. In The Biology and Conservation of the Callitrichidae, pp. 181-190. Ed. D. G. Kleiman. Smithsonian Press, Washington.

Kleiman, D.G., Gracey, D.W. \& Hodgen, G.D. (1978) Urinary chorionic gonadotropin levels in pregnant golden lion tamarins: Preliminary observations. $J$. med. Primatol. 7, 333-338.

Klopper, A. (1976) The choice between assays on blood or on urine. In Hormone Assays and Their Clinical Applications, pp. 73-86. Eds J. A. Loraine \& E. T. Bell. Churchill Livingstone, Edinburgh.
Lippold, L.K. (198I) Monitoring female reproductive status in the Douc langur, Pygathrix namaeus, at San Diego Zoo. Int. Zoo Ybk 21, 184-187.

Lunn, S.F. (1978) Urinary oestrogen excretion in the common marmoset, Callithrix jacchus. In Biology and Behaviour of Marmosets, pp. 67-74. Eds $\mathrm{H}$. Rothe, H.-J. Wolters \& J. P. Hearn. Eigenverlag-H. Rothe, Gottingen.

Mittermeier, R.A., Coimbra-Filho, A.F., Constable, I.D., Rylands, A.B. \& Valle, C. (1982) Conservation of primates in the Atlantic forest region of eastern Brazil. Int. Zoo Ybk 22, 2-17.

Rosenberger, A.L. \& Coimbra-Filho, A.F. (1984) Morphology, taxonomic status and affinities of the lion tamarins, Leontopithecus (Callitrichinae, Cebidae). Folia primatol. 42, 149-179.

Shackleton, C.H.L. (1974) Progesterone and oestrogen metabolism in the pregnant marmoset (Callithrix jacchus). J. Steroid Biochem. 5, 597-600.

Shackleton, C.H.L. (1975) Excretion of steroids by the adult marmoset monkey (Callithrix jacchus). $J$. Steroid Biochem. 6, 1429-1432.

Shandilya, L.N., Ramaswami, L.S. \& Shandilya, N. (1976) Oestrogen metabolites in urine during the menstrual cycle, pregnancy, and puerperium in the Indian hanuman langur (Presbytis entellus entellus). J. Reprod. Fert. 47, 7-11.

Shideler, S.E., Czekala, N.M., Benirschke, K. \& Lasley, B.L. (1983a) Urinary estrogens during pregnancy of the ruffed lemur (Lemur variegatus). Biol. Reprod. 28, 963-969.

Shideler, S.E., Czekala, N.M., Kasman, L.H., Lindburg, D.G. \& Lasley, B.L. (1983b) Monitoring ovulation and implantation in the lion-tail macaque (Macaca silenus) through urinary estrone conjugate evaluations. Biol. Reprod. 29, 905-911.

Tietz, N.W. (1976) Fundamentals of Clinical Chemistry. W. B. Saunders, Philadelphia.

Torii, R., Utsu, S. \& Tanioka, Y. (1981) Pituitary-adrenal function in the marmoset monkey. Acta endocr. jap. 57, 1177-1185.

Wilson, C.G. (1978) Gestation and reproduction in golden lion tamarins. In The Biology and Conservation of the Callitrichidae, pp. 191-192. Ed. D. G. Kleiman. Smithsonian Press, Washington.

Wolfe, L.G., Deinhardt, F., Ogden, J.D., Adams, M.R. \& Fisher, L.E. (1975) Reproduction of wild-caught and laboratory-born marmoset species used in biomedical research (Saguinus sp., Callithrix jacchus). Lab. Anim. Sci. 25, 802-813.

Received 4 March 1985 